\title{
Computational Thinking for Primary School Teachers: Building Problem-Solving and Literacy Skills
}

\author{
Maria Teodora Ping1, Yuni Utami Asih², Ida Wardani ${ }^{3}$ \\ 1 Mulawarman University, Samarinda, Indonesia \\ 2 Mulawarman University, Samarinda, Indonesia \\ ${ }^{3}$ Mulawarman University, Samarinda, Indonesia \\ 1mariateodoraping@fkip.unmul.ac.id, 2yuniutamiasih@fkip.unmul.ac.id, 3idawardani@fkip.unmul.ac.id
}

\begin{abstract}
Problem-solving is one of the skills that is crucial to equip students to face a variety of challenges in the future as well as related to the development of their lifelong literacy skills. One of the potential solutions for promoting students' problem-solving skills is introducing Computational Thinking. However, in the context of schools in East Kalimantan, both teachers and students have not been familiar with Computational Thinking. Therefore, this current pilot study aimed at introducing Computational Thinking to teachers, especially primary school teachers, by developing a workshop and a module suitable to the local contexts and needs. This study involved 22 primary school teachers from Kutai Kartanegara Regency who had no prior knowledge and experience concerning Computational Thinking. The teachers were trained the basic concepts of $\mathrm{CT}$ and how to implement CT in the class especially in relation to literacy aspects. Afterwards, the teachers were assigned to develop a CT-infused lesson and did a self-reflection on the process. The findings from the post-workshop questionnaires indicated that most teachers showed positive attitudes towards CT and implementing CT in their lessons. Furthermore, they also voiced out that they would like to learn further about CT, particularly related to Literacy and the Minimum Competency Assessment (AKM).
\end{abstract}

Keywords: computational thinking, literacy, teachers 


\section{INTRODUCTION}

The findings of the current Programme for International Student Assessment (PISA) 2018 has illustrated the low level of Indonesian students' reading, mathematics and science ability. The scores obtained by our students were far below the OECD average, which has become the national concerns. Furthermore, Organization for Economic Co-operation and Development (OECD) mentioned that in Indonesia, only 30\% of the students could reach Level 2 of the reading ability (compared with the average of $77 \%$ ). This indicates that only a few students could understand longer texts, find abstract concepts and identify the differences between facts and opinions. Meanwhile, in terms of the mathematics skills, only $28 \%$ of the students who could reach Level 2, with the minimum ability to interpret and identify how a simple situation can be represented mathematically (e.g. comparing distances) without explicit instructions. Moreover, only $1 \%$ of the Indonesian students could understand a complex situation mathematically as well as compare and evaluate strategic problem-solving.

Problem-solving skills are one of the crucial life skills that an individual should have in order to be able to compete in the Industrial Revolution 4.0 era (Care in Griffith and Care, 2018). This particular skill requires the ability to solve complex problems in real-time. Furthermore, it is necessary to master this skill because in the future, one will face a variety of problems which cannot be predicted at the moment. Along with the advancement of the society, the complexity of conflicts will also arise. In other words, the problem-solving skills are skills to identify a problem, determine the cause of the problem, identify priorities, choose possible solutions as well as implement those solutions. These skills require the ability of higher-order thinking or high- level reasoning, understanding the contents, implementing as well as transferring knowledge to solve the problems.

However, previous studies have revealed that the Indonesian primary and secondary school students still possess a low level of problem-solving skills. Studies conducted by Trisniawati (2017) in three different primary schools in Yogyakarta showed that in general our students could understand problems but most of them still could not plan a proper problemsolving strategy. In addition, Indriyani, Nurcahyono, and Agustiani (2018) indicated that Indonesian Junior High Schools were still unable to identify problems correctly, nor to determine appropriate problem-solving strategies as well as implement the problem-solving correctly. These findings provided an insight to the possible conditions that might have happened to other primary and secondary school students in Indonesia.

Problem-solving skills can be developed through many ways, one of which is Computational Thinking. Computational Thinking itself is defined as thinking to solve problems by using procedures that can be used by both human and computers (Hoppe and Werneburg, 
2019). Moreover, CT is a basic skill that should be mastered by everyone. In practice at schools, CT develops problem-solving skills, in which students will be trained to identify problems, understand those problems and then develop possible solutions. CT involves four pillars or cornerstones, namely decomposition, pattern recognition, abstraction, and algorithms. By applying these cornerstones, it is expected that students are able to think systematically and strategically in solving a particular problem. However, in the context of schools in East Kalimantan Province, problem-solving skills have not been a familiar practice. Therefore, this current pilot study was conducted, with a special aim at introducing Primary School teachers, particularly in Kutai Kartanegara Regency, East Kalimantan Province to Computational Thinking, as one of the potential ways to promote problem-solving skills for their students. In addition, CT in this study would be conveyed under the framework of building literacy skills.

\section{METHOD}

This pilot study adapted a model of 'design and research development process' by Saunders (2015) as illustrated in Figure 1 below.

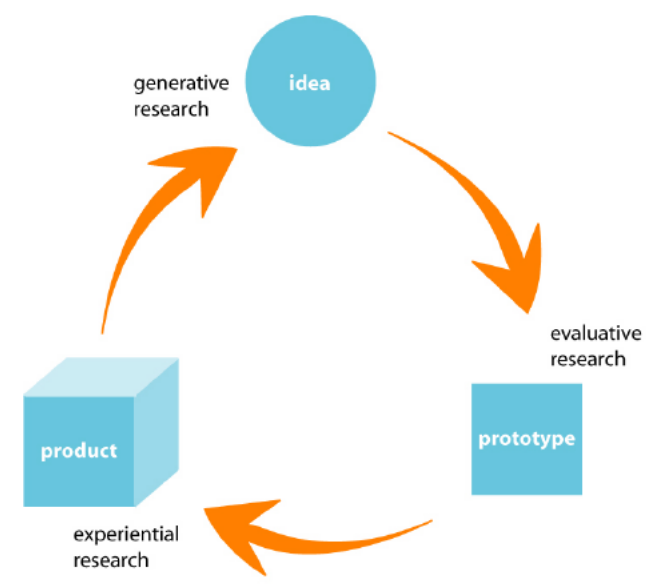

Figure 1. Design and Research Development Process

There were four stages done in this pilot study, as follows:

Stage 1. Developing the Computational Thinking Training Module for Primary School Teachers (Idea and Prototype)

Stage 2. Implementing Computational Workshop for Primary School Teachers (Experiential Research)

Stage 3. Evaluating the Module and Workshop Procedure

Stage 4. Revising the Module and Workshop Procedure (Product) 
The participants of this pilot study were a group of Primary School Teachers from Kutai Kartanegara Regency that were recruited on voluntary basis. The intervention (i.e. workshop) was done both synchronously (via web meeting) and asynchronously (independent assignments and feedback). The data for this study were obtained from the evaluation questionnaire results (quantitative) and teachers' narrative reflections (qualitative). Furthermore, the data were analysed by using descriptive statistics and simple thematic analysis.

\section{RESULT AND DISCUSSION}

The findings of the 7-item questionnaire indicated that most teachers showed a positive attitude towards Computational Thinking and the workshop. The following examples of charts will illustrate the teachers' evaluation towards learning Computational Thinking through the workshop and whether they would like to implement Computational Thinking in their own teaching especially related to developing literacy skills of the students.

\section{Question 1: the CT workshop materials are easy to understand}

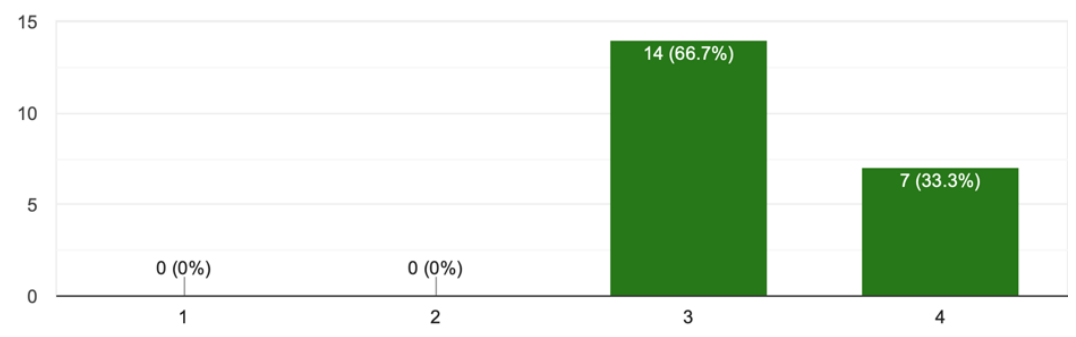

Figure 2. Question 1 Response

As seen from the bar chart above, all of the teachers agreed that the CT workshop materials (module) prepared by the research team were easy to understand. The similar trend occurred when they were asked whether the materials were relevant to their needs- especially in terms of preparing their students for the Minimum Competence Assessment, as shown by Figure 3 below. 


\section{Question 2: the materials are relevant to the teachers' needs}

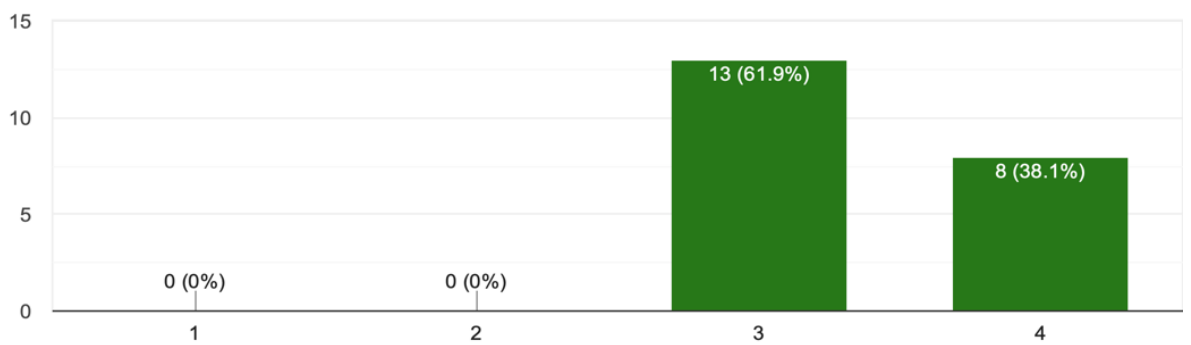

Figure 3. Question 2 Response

Eventually, most teachers also agreed that they wanted to implement Computational Thinking in their own classrooms sometime in the near future, as depicted by Figure 4 below.

\section{Question 7: the teachers are willing to implement CT in their lessons}

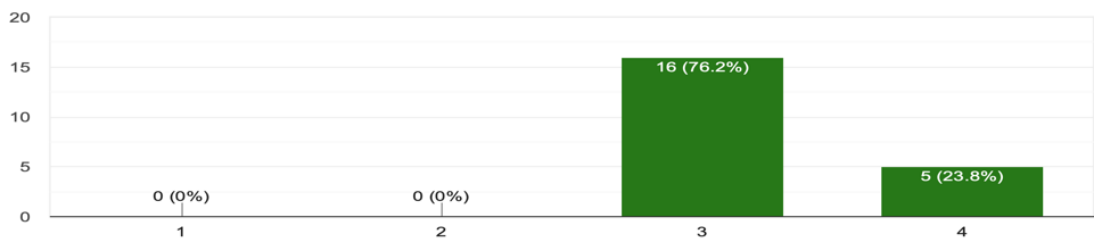

Figure 4. Question 7 Response

In addition, for the narrative reflections, most teachers expressed that through the workshop activities, they had understood the basic concepts of CT in relation to Literacy (AKM). However, most of the participating teachers would like to learn more about CT as well. These reflections can be seen from Figure 5 below.

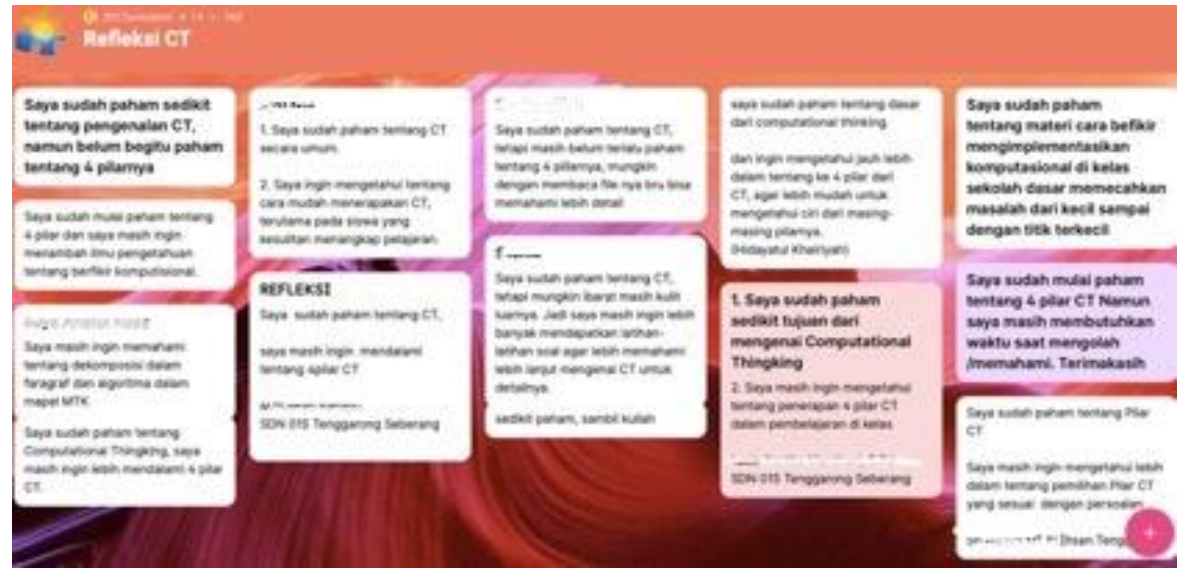

Figure 5. Teachers' Narrative Reflection 


\section{CONCLUSION}

The results of this pilot study generate the conclusion below:

1. Primary School teachers who participated in this pilot study showed a positive attitude towards Computational Thinking and learning Computational Thinking to build their students' problem-solving and literacy skills.

2. The materials and workshop provided in this pilot study were considered as helpful and relevant by the participating teachers.

Furthermore, based on the teachers' reflections and suggestions, the following implications should be considered:

1. It is possible to introduce computational thinking at primary school levels to develop problem-solving skills and literacy skills.

2. More intensive training is necessary for primary school teachers in order to be able to implement Computational Thinking, especially to further build literacy skills, in their lessons.

\section{ACKNOWLEDGEMENT (if needed)}

The authors would like to thank the Faculty of Teacher Training and Education, Mulawarman University, for providing the grant to financially support this community servicebased pilot study.

\section{REFERENCES}

Care, E. (2018) Thwenty-First Century Skills: From Theory to Action. In Assessment and Teaching of 21st Century Skills Research and Applications. Griffin, P. and Care, E. (Eds.). Switzerland: Springer.

Hoppe, H.U. \& Werneburg, S. (2019). Computational Thinking-More Than a Variant of Scientific Inquiry! In S.-C. Kong \& H. Abelson (Eds.), Computational Thinking Education (pp. 13-30). Singapore: Springer.

Indriyani, F., Nurcahyono, N. A., dan Agustiani, N. 2018. Analisis Kemampuan Pemecahan Masalah Siswa berdasarkan Langkah Ideal Problem Solving. Pythagoras 7(2):56-67.

Sanders, Elizabeth B-N. 2015. Information, Inspiration and Co-creation. Paper presented at The 6th International Conference of the European Academy of Design, March 29-31 2005,

University of the Arts, Bremen, Germany

Trisniawati. Analisis Kemampuan Pemecahan Masalah Matematis Siswa Tingkat Sekolah Dasar di Kotamadya Yogyakarta. Science Tech: Jurnal Ilmu Pengetahuan dan Teknologi, 3(1), 110, Jan 2017. doi:http://dx.doi.org/10.30738/jst.v3i1.1135 